Politica, Vol. 7, No. 2, Juli-Desember 2020

\title{
KOMISI YUDISIAL DALAM PENEGAKAN KODE ETIK DAN PEDOMAN PERILAKU HAKIM
}

\author{
Oleh: Orien Effendi \\ Program Magister Ilmu Syari'ah Fakultas Syari'ah dan Hukum \\ Universitas Islam Negeri Sunan Kalijaga Yogyakarta \\ e-mail: orieneffendi3@gmail.com
}

\begin{abstract}
Abstrak
Komisi Yudisial Dalam Penegakan Kode Etik Dan Pedoman Perilaku Hakim. Masih terdapatnya dugaan pelanggaran Kode Etik dan Pedoman Perilaku Hakim di lembaga peradilan telah mencederai nilai-nilai keadilan. Kasus para penegak hukum di lembaga peradilan seperti adanya suap menyuap telah memberikan gambaran akan perlunya pengawasan dalam lembaga peradilan, selain keberadaan Mahkamah Agung (MA) sebagai pengawas internal yang dinilai tidak mampu mencegah para penegak hukum di lembaga peradilan melakukan pelanggaran Kode Etik dan Pedoman Perilaku Hakim. Komisi Yudisial (KY) sebagai lembaga pengawas ekternal berperan menegakkan Kode Etik dan Pedoman Perilaku Hakim agar terciptanya peradilan yang bersih. Permasalahan dalam lembaga peradilan tersebut di analisa dengan pendekatan kepustakaan, dalam menganalisa pemberitaan media dengan melihat fakta-fakta yang terjadi di lingkungan peradilan, ditemukannya pelanggaran kode etik profesi sebagai penegak keadilan di lembaga perdilan.
\end{abstract}

Kata Kunci: Hakim, Kode Etik, Lembaga Peradilan, MA, KY

\section{A. Pendahuluan}

Banyak kalangan yang menyebutkan dasar dari pembentukan Komisi Yudisial karena pengadilan telah menjadi lembaga yang dinilai korup (judicial corruption) dan penuh dengan praktik-praktik yang sangat mencederai nilai-nilai keadilan, seperti dengan adanya suap menyuap dan lain sebagainya. Praktik tersebut seperti sangat sulit dihentikan, sebab bukan hanya sekali kasus suap menyuap atau praktik semacam itu terjadi dalam ruang lingkup ranah peradilan kita dewasa 
ini, terlebih ketika pengawasan internal tidak mampu mengendalikannya dengan semaksimal mungkin. Oleh karena itu, Komisi Yudisial kemudian dibentuk dengan semangat untuk mengembangkan sistem pengawasan eksternal.

Sebagai pengawas eksternal, Komisi Yudisial menjalankan wewenang dan tugasnya berupa pengawasan preventif dalam bentuk seleksi hakim agung sebagai wewenang dan tugas konstitusional yang berupa mengusulkan pengangkatan hakim agung. Selain berupa pengawasan preventif, Komisi Yudisial juga mempunyai wewenang lain dalam rangka menjaga dan menegakkan kehormatan, keluhuran martabat, serta perilaku hakim sebagaimana dimuatkan dalam Pasal 24B. ${ }^{1}$

Penyalahgunaan wewenang di badan peradilan mencederai seluruh nilai peradilan. Dampaknya kepercayaan masyaralat terhadap peradilan di Indonesia pun menjadi menurun. ${ }^{2}$ Tentu hal tersebut tidak kita harapkan semakin berlanjut karena melalui badan peradilan adalah harapan terakhir masyarakat mendapatkan keadilan. Bilamana lembaga peradilan juga di cederai oleh oknum-oknum yang tidak bertanggung jawab maka kemana masyarakat mencari keadilan. Keadaan ranah peradilan tersebut diperlukannya upaya agar kepercayaan masyarakat terhadap lembaga peradilan kembali menguat untuk mencari keadilan.

Hadirnya Komisi Yudisial sebagai lembaga pengawasan tentu muncul akibat kenyataan yang di mana pengawasan yang dilakukan internal dalam peradilan itu sendiri sangatlah lemah. Beberapa kasus penyalahgunaan wewenang terus saja terjadi. Asumsi masyarakat adanya kongkalikong dalam peradilan seakan tidak terbantahkan, sebab itu hadirnyan pengawasan dari luar yakni Komisi Yudisial sebagai lembaga pengawas menjadi harapan baru agar terciptanya peradilan yang bersih.

${ }^{1}$ Komisi Yudisial dibentuk berdasarkan Pasal 24B Perubahan Ketiga UUDNRI Tahun 1945 yang menyatakan bahwa Komisi Yudisial bersifat mandiri yang berwenang mengusulkan pengangkatan hakim agung dan mempunyai wewenang lain dalam rangka menjaga dan menegakkan kehormatan, keluhuran martabat, serta perilaku hakim.

${ }^{2}$ Nur Ahsan, 'Komisi Yudisial Dalam Pengawasi Hakim Perspektif Peradilan Islam”, Jurnal Agama Dan Hak Azazi Manusia, Vol. 2, Nomor 2 Mei 2013, pp. 308. 
Sebagaiamana yang kita ketahui beberapa waktu yang lalu eks hakim konstitusi Patrialis Akbar dituntut hukuman penjara 8 (delapan) tahun ditambah denda Rp.300.000.000 (Tiga ratus juta rupiah) subsider 3 (tiga) bulan kurungan penjara. ${ }^{3}$ Patrialis juga didakwa membayar uang pengganti sejumlah Rp.4.043.195 (empat juta empat puluh tiga ribu seratus sembilan puluh lima rupiah), dan sejumlah US\$ 10.000 (sepuluh ribu dolar Amerika Serikat), dengan ketentuan apabila Terdakwa Patrialis Akbar tidak membayar uang pengganti tersebut dalam waktu satu bulan setelah putusan pengadilan memperoleh kekuatan hukum tetap, maka harta bendanya akan disita oleh Jaksa dan dilelang untuk menutupi uang pengganti tersebut.

Dalam hal terdakwa tidak mempunyai harta benda yang mencukupi untuk membayar pengganti tersebut, maka dipidana penjara selama 6 (enam) bulan. Sebelumnya Jaksa menyatakan Patrialis Akbar terbukti melakukan korupsi untuk mempengaruhi perkara nomor 129/PUU-XIII/2015 terkait permohonan uji materi UU nomor 41/2014 tentang Peternakan dan Kesehatan Hewan. ${ }^{4}$ Menurut Jaksa, Patrialis Akbar terbukti menerima hadiah atau janji dari Basuki Hariman dan $\mathrm{Ng}$ Fenny selaku pemohon perkara nomor 129/PUU-XIII/2015.

Dalam putusan hakim di Pengadilan Negeri Jakarta Pusat, Hakim konstitusi sekaligus mantan Ketua MK, Akil Mochtar juga dinyatakan terbukti bersalah menerima hadiah dan tindak pidana pencucuian uang terkait kasus sengketa Pilkada di $\mathrm{MK}^{5}$. Akil Mochtar sebelumnya dinyatakan sebagai tersangka kasus suap penanganan perkara pilkada Kabupaten Gunung Mas, Kalimantan Tengah dan Kabupaten Lebak, Banten. Akil Mochtar ditangkap KPK pada awal Oktober 2013. Dalam penangkapan itu KPK menyita mata uang dollar Singapura serta dollar

${ }^{3}$ Direktori Putusan Mahkamah Agung Republik Indonesia Nomor 81/Pid.SusTPK/2017/PN.Jkt.Pst. Tentang Tindak Pidana Korupsi Secara Besama-sama Dan Berlanjut.

${ }^{4}$ Aditya Mardiastuti, 'Kasus Suap Di MK', dalam http//www.detik News.com, diakses tanggal 01 Juni 2020, Pukul 10.25.

${ }^{5}$ Direktori Putusan Mahkamah Agung Republik Indonesia Nomor 10/Pid.SusTPK/2014/PN.Jkt.Pst. Tentang Tindak Pidana Pencucian Uang Sengketa Pilkada Di MK. 
AS senilai kurang lebih Rp 3 milliar. Dalam perkara ini Akil Mochtar mendapatkan hukuman pidana penjara selam seumur hidup. ${ }^{6}$

Kasus penyalahgunaan wewenang dalam ranah peradilan di atas memberikan gambaran kepada kita bawa keberadaan dewan etik di Mahkamah Konstitusi dianggap tidak cukup untuk mengawasi tindakan dan perilaku hakim di lembaga tersebut. Beberapa waktu yang lalu Komisi Yudisial (KY) kembali diusulkan untuk memperkuat pengawasan terhadap hakim konstitusi. UU Nomor 22 Tahun 2004 tentang Komisi Yudisial sebenarnya telah menyebut MK masuk dalam objek pengawasan KY. Namun, pengawasan terhadap MK tak bisa lagi dilakukan pasca Mahkamah Agung melakukan judicial review atas peraturan tersebut. Banyak kalangan menilai ketiadaan pengawasan oleh Komisi Yudisial sebagai pihak ekternal menjadi sebab hakim konstitusi terjerat kasus korupsi dan suap.

Dibentuknnya Komisi Yudusial diharapkan dapat mengawasi peradilan di Indonesia dan mampu menjadi pengawas agar para hakim untuk mendorong terciptanya peradilan yang bersih. Komisi Yudisial diharapkan mampu menjadi pengawas ekternal terhadap perilaku hakim dan lembaga peradilan itu sendiri. Sedangkan Mahkamah Agung memilki peran sebagai pengawas internal bagi para hakim atau lembaga peradilan. Dua lembaga yakni Komisi Yudisial dan Mahkamah Agung ini menjadi kontrol agar terciptanya peradilan yang bersih, bilamana hakim berpedoman pada Kode Etik dan/atau Pedoman Perilaku Hakim sebagaimna Keputusan Bersama Ketua Mahkamah Agug RI dan Ketua Komisi Yudisial RI No. 047/KMA/SKB/IV/2009 garis miring 02/SKB/P.KY/ IV/2009 tentang Kode Etik dan Pedoman Perilaku Hakim. $^{7}$

Adapun sebelumnya Mahkamah Agung telah mengadakan kajian dengan memperhatikan masukan dari Hakim di berbagai tingkatan lingkungan peradilan, kalangan praktisi hukum, akademisi hukum,

${ }^{6}$ Icha Rastika,'Penangkapan Akil Mochtar', dalam http//www.kompas.com, diakses tanggal 01 Juni 2020, Pukul 10.30.

${ }^{7}$ Keputusan Bersama Ketua Mahkamah Agung RI Dan Ketua Komisi Yudisial RI tentang Kode Etik Dan Pedoman Perilaku Hakim, Nomor. 047/KMA/SKB/IV/2009 dan 02/SKB/P.KY/IV/2009. 
serta pihak-pihak lain dalam masyarakat untuk menyusun Kode Etik dan Pedoman Perilaku Hakim ini. Selain itu memperhatikan hasil perenungan ulang atas pedoman yang pertama kali dicetuskan dalam Kongres IV Luar Biasa IKAHI Tahun 1966 di Semarang, dalam bentuk Kode Etik Hakim Indonesia dan disempurnakan kembali dalam Munas XIII IKAHI Tahun 2000 di Bandung.

Untuk selanjutnya ditindaklanjuti dalam Rapat Kerja Mahkamah Agung RI Tahun 2002 di Surabaya yang merumuskan 10 (sepuluh) prinsip Pedoman Perilaku Hakim yang didahului pula dengan kajian mendalam yang meliputi proses perbandingan terhadap prinsip-prinsip Internasional, maupun peraturan-peraturan serupa yang ditetapkan di berbagai negara, antara lain The Bangalore Principles of Yudicial Conduct. Selanjutnya Mahkamah Agung menerbitkan pedoman perilaku Hakim melalui Surat Keputusan Ketua Mahkamah Agung RI Nomor: KMA/104A/SK/XII/2006 tanggal 22 Desember 2006, tentang Pedoman Perilaku Hakim dan Surat Keputusan Ketua Mahkamah Agung RI Nomor: 215/KMA/ SK/XII/2007 tanggal 19 Desember 2007 tentang Petunjuk Pelaksanaan Pedoman Perilaku Hakim.

Demikian pula Komisi Yudisial RI telah melakukan pengkajian yang mendalam dengan memperhatikan masukan dari berbagai pihak melalui kegiatan Konsultasi Publik yang diselenggarakan di 8 (delapan) kota yang pesertanya terdiri dari unsur hakim, praktisi hukum, akademisi hukum, serta unsur-unsur masyarakat termasuk lembaga swadaya masyarakat.

Berdasarkan pertimbangan-pertimbangan tersebut di atas dan memenuhi pasal 32A jo pasal 81B Undang-Undang Nomor 3 Tahun 2009 tentang Perubahan Kedua Undang-Undang Nomor 14 Tahun 1985 tentang Mahkamah Agung, maka disusunlah Kode Etik dan Pedoman Perilaku Hakim yang merupakan pegangan bagi para Hakim seluruh Indonesia serta Pedoman bagi Mahkamah Agung RI dan Komisi Yudisial RI dalam melaksanakan fungsi Pengawasan internal maupun eksternal. ${ }^{8}$

\footnotetext{
${ }^{8}$ Ibid., hlm. 4-5.
} 
Prinsip-prinsip dasar Kode Etik dan Pedoman Perilaku Hakim diimplementasikan dalam 10 (sepuluh) aturan perilaku sebagai berikut: (1) Berperilaku Adil, (2) Berperilaku Jujur, (3) Berperilaku Arif dan Bijaksana, (4) Bersikap Mandiri, (5) Berintegritas Tinggi, (6) Bertanggung Jawab, (7) Menjunjung Tinggi Harga Diri, (8) Berdisiplin Tinggi, (9) Berperilaku Rendah Hati, (10) Bersikap Profesional.

\section{B. Tujuan Pengawasan Hakim Dalam Peradilan}

\section{Terciptanya Peradilan Yang Bersih}

Dalam rangka terciptanya lembaga peradilan yang bersih Komisi Yudisial sebagai lembaga pengawas ekternal memiliki wewenang dan tugas sebagaimana yang disebutkan dalam Undang-undang Republik Indonesia Nomor 18 Tahun 2011 tentang Perubahan Atas Undangundang Nomor 22 Tahun 2004 tentang Komisi Yudisial. Terdapat wewenang dan tugas pada Pasal 13 sebagaimana Komisi Yudisial memiliki wewenang dan tugas diatara lain: ${ }^{9}$ (1) Mengusulkan pengangkatan hakim agung dan hakim ad hoc di Mahkamah Agung kepada DPR untuk mendapatkan persetujuan, (2) Menjaga dan menegakkan kehormatan, keluhuran martabat, serta perilaku hakim, (3) Menetapkan Kode Etik dan/atau Pedoman Perilaku Hakim bersamasama dengan Mahkamah Agung, (4) Menjaga dan menegakkan pelaksanaan Kode Etik dan/atau Pedoman Perilaku Hakim.

Dalam rangka menjaga dan menegakkan kehormatan, keluhuran martabat, serta perilaku hakim dengan menjalankan tugas dan wewenang Komisi Yudisial agar Kode Etik dan/atau Perilaku Hakim dapat dipatuhi sebagimana mestinya. Komisi Yudisial mempergunakan wewenang dan tugasnya sebagaimana disebutkan dalam Pasal 20 Undang-undang Republik Indonesia Nomor 18 Tahun 2011 tentang Perubahan Atas Undang-undang Nomor 22 Tahun 2004 tentang Komisi Yudisial, terdapat wewenang dan tugas dalam melakukan pemantauan dan pengawasan terhadap perilaku hakim. Sebagaimana implementasi dari pasal tersebut adalah langkah maupun singkap Komisi Yudisial dalam melakukan pemantauan persidangan berdasarkan laporan dari

${ }^{9}$ Undang-undang Republik Indonesia Nomor 18 Tahun 2011 tentang Perubahan Atas Undang-undang Nomor 22 Tahun 2004 Tentang Komisi Yudisial. 
Politica, Vol. 7, No. 2, Juli-Desember 2020

masyarakat yang sebelumnya akan di verifikasi, klarifikasi, dan investigasi terhadap dugaan pelanggaran Kode Etik dan/atau Pedoman Perilaku Hakim secara tertutup berdasarkan laporan masyarakat tersebut.

\section{Terciptanya Keadilan Bagi Masyarakat}

Bahwa keadilan merupakan kebutuhan pokok rohaniah setiap orang dan merupakan perekat hubungan sosial dalam bernegara. Pengadilan merupakan tiang utama dalam penegakan hukum dan keadilan serta dalam proses pembangunan peradaban bangsa. Tegaknya hukum dan keadilan serta penghormatan terhadap keluhuran nilai kemanusiaan menjadi prasyarat tegaknya martabat dan integritas Negara. Hakim sebagai figure sentral dalam proses peradilan senantiasa dituntut untuk mengasah kepekaan nurani, memelihara kecerdasan moral dan meningkatkan profesionalisme dalam menegakkan hukum dan keadilan bagi masyarakat banyak. Putusan Pengadilan yang adil menjadi puncak kearifan bagi penyelesaian pemasalahan hukum yang terjadi dalam kehidupan bernegara. ${ }^{10}$

Putusan Pengadilan yang diucapkan dengan irah-irah "Demi Keadilan Berdasarkan Ketuhanan Yang Maha Esa" menunjukkan kewajiban menegakkan keadilan yang dipertanggungjawabkan secara horizontal kepada sesama manusia dan vertikal kepada Tuhan Yang Maha Esa.

Meski tidak dijelaskan secara eksplisit atas kewajiban Komisi Yudisial dalam melayani masyarakat agar terciptanya lembaga peradilan yang bersih, bunyi Pasal 20 Undang-undang Republik Indonesia Nomor 18 Tahun 2011 tentang Perubahan Atas Undangundang Nomor 22 Tahun 2004 tentang Komisi Yudisial, secara tidak langsung Komisi Yudisial sebagai lembaga pengawas ekternal berkewajiban melayani kebutuhan masyarakat dalam ranah peradilan, Komisi Yudisial seakan-akan menjadi harapan utama masyarakat agar

${ }^{10}$ Keputusan Bersama Ketua Mahkamah Agung RI Dan Ketua Komisi Yudisial RI tentang Kode Etik Dan Pedoman Perilaku Hakim, Nomor. 047/KMA/ SKB/IV/2009 dan 02/SKB/P.KY/IV/2009. 
terciptanya peradilan yang bersih dan berkeadilan yang di mana bersama-sama masyarakat mengawasi lembaga peradilan di Indonesia.

Komisi Yudisial (KY) Nusa Tenggara Barat (NTB) merekomendasikan 7 (tujuh) hakim di NTB mendapatkan sanksi. Ketujuh hakim tersebut diduga telah melakukan pelanggaran etik di wilayah yudiksi pengadilan tinggi NTB. 'Kasus di NTB ini masuk urutan ke 7 (tujuh) dari 34 provinsi di Indonesia. Dari 27 (dua puluh tujuh) hakim yang dilaporkan., kami merekomendasikan 7 (tujuh) hakim terancam mendapatkan sanksi dari Mahkamah Agung ," Kata Koordinator Penghubung KY, Ridho Adrian Pratama kepada Kompas.com di kantornya, Jumat (13/3/2020). Laporan tersebut masuk pada 2 (dua) Januari hingga 23 Desember 2019. ${ }^{11}$

Adanya dugaan pelanggaran Kode Etik dan/atau Pedoman Perilaku Hakim di wilayah yudiksi pengadilan tinggi Nusa Tenggara Barat (NTB) di atas sebagai gambaran bahwa keberadaan lembaga Komisi Yudisial sebagai pengawas ekternal ditengah-tengah masyarakat sangatlah penting. Dari jumlah hakim yang akan direkomendasikan akan diberikan sanksi di wilayah yudiksi pengadilan tinggi Nusa Tenggara Barat (NTB) di atas menggambarkan seakan-akan lembaga peradilan kita masih belum bersih dan tidak menutup kemungkinan masih terdapat ketidak sesuaian terutama bagi para hakim dalam menjalankan Kode Etik dan/atau Pedoman Perilaku Hakim.

Dalam Undang-undang Republik Indonesia Nomor 18 Tahun 2011 tentang Perubahan Atas Undang-undang Nomor 22 Tahun 2004 tentang Komisi Yudisial, disebutkan dalam pasal 20A ayat (1) poin c Komisi Yudisial wajib menjaga kerahasiaan keterangan atau informasi yang diperoleh yang karena sifatnya merupakan rahasia Komisi Yudisial yang diperoleh berdasarkan kedudukannya sebagai anggota. ${ }^{12}$ Meski demikian dengan tidak di publikasikannya mana saja laporan masyarakat yang berujung penindakan atau pemberian sanksi terhadap

11 Fitri Rachmawati, 'Komisi Yudisial", dalam http//www.kompas.com, diakses tanggal 06 Juni 2020, Pukul 21.00.

12 Pasal 20A ayat (1) Poin c Undang-undang Republik Indonesia Nomor 18 Tahun 2011 tentang Perubahan Atas Undang-undang Nomor 22 Tahun 2004 tentang Komisi Yudisial. 
dugaan pelanggaran Kode Etik dan/atau Pedoman Perilaku Hakim, kita dapat meyakini bahwa kinerja dari lembaga Komisi Yudisial sebagai pengawas ekternal patut kita apresiasi dan sangat diperlukan demi tercapainya keadilan bagi masyarakat dalam beperkara atau mencari keadilan di lembaga peradilan.

\section{Komisi Yudisial Dalam Penegakan Kode Etik Hakim}

Kewenangan Komisi Yudisial yang dijabarkan dalam UndangUndang Nomor 22 Tahun 2004 tentang Komisi Yudisial yang membagi menjadi dua kewenangan yaitu: ${ }^{13}$ Pertama, Mengusulkan pengangkatan calon hakim agung kepada Dewan Perwakilan Rakyat; Kedua, Menjaga dan menegakkan kehormatan, keluhuran martabat serta perilaku hakim. Wewenang Komisi Yudisial diperluas melalui perubahan peraturan perundang-undangan di bidang kekuasaan kehakiman yaitu wewenang untuk melakukan seleksi pengangkatan hakim bersama Mahkamah Agung sebagaimana diatur dalam Undang-Undang Nomor 48 Tahun 2009 tentang Kekuasaan Kehakiman ${ }^{14}$, Undang-Undang Nomor 49 Tahun 2009 tentang Perubahan Kedua Atas Undang-Undang Nomor 2 Tahun 1986 tentang Peradilan Umum ${ }^{15}$, Undang-Undang Nomor 50 Tahun 2009 tentang Perubahan Kedua Atas Undang-Undang Nomor 7 Tahun 1989 tentang Peradilan Agama ${ }^{16}$, dan Undang-Undang Nomor 51 Tahun 2009 tentang Perubahan Kedua Atas Undang-Undang Nomor 5 Tahun 1986 tentang Peradilan Tata Usaha Negara ${ }^{17}$. Dengan demikian berdasarkan peraturan perundang-undangan di atas, wewenang Komisi Yudisial adalah sebagai berikut:

${ }^{13}$ Undang-undang Nomor 22 Tahun 2004 tentang Komisi Yudisial.

${ }^{14}$ Undang-Undang Nomor 48 Tahun 2009 tentang Kekuasaan Kehakiman.

15 Undang-Undang Nomor 49 Tahun 2009 tentang Perubahan Kedua Atas Undang-Undang Nomor 2 Tahun 1986 tentang Peradilan Umum.

16 Undang-Undang Nomor 50 Tahun 2009 tentang Perubahan Kedua Atas Undang-Undang Nomor 7 Tahun 1989 tentang Peradilan Agama.

${ }_{17}$ Undang-Undang Nomor 51 Tahun 2009 tentang Perubahan Kedua Atas Undang-Undang Nomor 5 Tahun 1986 tentang Peradilan Tata Usaha Negara. 
Politica, Vol. 7, No. 2, Juli-Desember 2020

\section{Mengusulkan Pengangkatan Calon Hakim Agung}

Pelaksanaan wewenang mengusulkan pengangkatan calon hakim agung dilakukan dengan kebijakan berupa Peraturan Komisi Yudisial Nomor 2 Tahun 2009 tentang Tata Cara Seleksi Calon Hakim Agung. Berdasarkan peraturan tersebut, seleksi calon hakim agung dilakukan dengan tahapan; Pertama, Seleksi Administratif; Kedua, Seleksi Kualitas, Kepribadian, dan Kesehatan; Ketiga, Investigasi, Wawancara, dan Penentuan Akhir. Pada tahun 2010-2011 seleksi calon hakim agung telah dilaksanakan 2 kali dengan menghasilkan 24 calon hakim agung yang diusulkan kepada DPR. Permasalahan yang masih menjadi kendala dalam pelaksanaan seleksi calon hakim agung antara lain; Pertama, Kesesuaian antara kualifikasi dan spesifikasi hakim agung yang butuhkan MA dengan calon hakim agung yang lulus seleksi; Kedua, Keterbatasan jumlah SDM bakal calon hakim agung yang memenuhi persyaratan dan mau mencalonkan diri, dan Ketiga, Perbedaan kapasitas calon hakim agung yang berasal dari karier dan non karier.

Berdasarkan permasalahan tersebut, Komisi Yudisial telah mengeluarkan Peraturan Komisi Yudisial Nomor 7 Tahun 2011 tentang Perubahan Atas Peraturan Komisi Yudisial Nomor 2 Tahun 2009 tentang Tata Cara Seleksi calon Hakim Agung. ${ }^{18}$ Peraturan ini telah diterapkan dalam penyelenggaraan seleksi calon hakim agung pada tahun 2011. Permasalahan kesesuaian antara kualitas dan spesifikasi hakim agung yang dibutuhkan Mahkamah Agung dengan calon hakim yang lulus seleksi sudah mulai dapat diatasi melalui koordinasi dengan Mahkamah Agung, dimana kualifikasi dan spesifikasi hakim agung yang dibutuhkan Mahkamah Agung telah disampaikan pada saat Mahkamah Agung mengajukan kebutuhan hakim agung kepada Komisi Yudisial.

${ }^{18}$ Peraturan Komisi Yudisial Nomor 7 Tahun 2011 tentang Perubahan Atas Peraturan Komisi Yudisial Nomor 2 Tahun 2009 tentang Tata Cara Seleksi calon Hakim Agung. 
Politica, Vol. 7, No. 2, Juli-Desember 2020

\section{Menjaga Dan Menegakkan Kehormatan, Keluhuran Martabat Serta Perilaku Hakim}

Pelaksanaan wewenang menjaga dan menegakkan kehormatan, keluhuran martabat, serta perilaku hakim dilaksanakan dengan kebijakan yang dituangkan dalam Peraturan Komisi Yudisial Nomor 4 Tahun 2009 tentang Tata Cara Penanganan Laporan Pengaduan Masyarakat. Berdasarkan peraturan tersebut, penanganan laporan pengaduan masyarakat mengenai dugaan pelanggaran Kode Etik dan/atau Pedoman Perilaku Hakim (KEPPH) dilakukan dengan tahapan: ${ }^{19}$ Pertama, Penerimaan laporan pengaduan masyarakat dan registrasi; Kedua, Anotasi, Investigasi, dan Pemantauan; Ketiga, Pleno I untuk memutuskan laporan dapat ditindaklanjuti atau tidak; Keempat, Pemeriksaan Pelapor, Saksi, Ahli, dan Terlapor; Kelima, Pleno II untuk memutuskan terbukti atau tidaknya dugaan pelanggaran KEPPH; Keenam, Penyampaian rekomendasi sanksi kepada Mahkamah Agung dan Pembentukan Majelis Kehormatan Hakim (MKH).

Permasalahan yang terjadi dalam pelaksanaan wewenang ini adalah: Pertama, waktu penanganan laporan yang relatif lama; Kedua, belum didukung dengan sistem informasi; Ketiga, sistem administrasi penanganan laporan pengaduan masyarakat yang belum tertib; Keempat, belum ada standar yang baku kemampuan teknis pegawai yang bertugas menangani laporan pengaduan masyarakat. Untuk mengatasi beberapa permasalahan tersebut sudah dilakukan perubahan peraturan dengan dikeluarkannya Peraturan Komisi Yudisial Nomor 4 Tahun 2011 tentang Tata Cara Penangan Laporan Masyarakat, namun demikian peraturan tersebut belum dapat dilaksanakan secara optimal dan perlu menempuh langkah-langkah konkrit untuk peningkatan penanganan laporan masyarakat secara cepat, murah, dan mudah diakses masyarakat.

Oleh sebab itu Komisi Yudisial kembali menerbitkan Undangundang Repubulik Indonesia Nomor 18 Tahun 2011 tentang Perubahan Atas Undang-undang Nomor 22 Tahun 2004 tentang Komisi Yudisial, dengan tujuan agar memperkuat kinerja Komisi Yudisial sebab

19 Peraturan Komisi Yudisial Nomor 4 Tahun 2009 tentang Tata Cara Penanganan Laporan Pengaduan Masyarakat. 
Politica, Vol. 7, No. 2, Juli-Desember 2020

memiliki landasan hukum yang kuat terhadap wewenang yang di miliki Komisi Yudisial. $^{20}$

\section{Melakukan Seleksi Pengangkatan Hakim Bersama-sama Mahkamah Agung}

Wewenang melakukan seleksi pengangkatan hakim bersama-sama dengan MA sampai sekarang belum dapat dilaksanakan. Upaya yang telah dilakukan adalah mengadakan koordinasi dengan Mahkamah Agung untuk merancang seleksi pengangkatan hakim secara bersamasama. Mahkamah Agung baru merespon pada akhir tahun 2011 yang ditindaklanjuti dengan pembentukan Tim Penghubung KY-MA untuk membahas secara mendalam beberapa isu strategis berkaitan dengan pelaksanaan wewenang masing-masing yang diharapkan dapat berjalan secara sinergis. Permasalahan yang muncul dalam pembahasan di Tim Penghubung pada dasarnya berupa perbedaan persepsi mengenai status hakim sebagai Pejabat Negara atau hakim sebagai Pegawai Negeri Sipil (PNS) yang mempunyai konsekuensi logis terhadap pelaksanaan seleksi hakim.

Dalam rangka mendukung pelaksanaan wewenang sebagaimana diuraikan di atas, Sekretariat Jenderal Komisi Yudisial secara berkelanjutan telah berupaya untuk meningkatkan kapasitas kelembagaan melalui penambahan jumlah pegawai, peningkatan kapasitas SDM/pegawai, membangun kerjasama kemitraan dengan jejaring, dan penggunaan anggaran secara efisien, efektif, dan tepat sasaran.

Permasalahan yang masih dihadapi dalam peningkatan kapasitas kelembagaan ini antara lain; Pertama, masih kurangnya kualitas dan kuantitas SDM yang menguasai dibidang teknis investigasi, anotasi, pemeriksaan, dan kemampuan teknis lainnya; Kedua, Masih lemahnya dukungan sistem informasi; Ketiga, masih rendahnya dukungan anggaran yang ada. Pemerintah bersama DPR telah mengesahkan Undang-Undang Nomor 18 Tahun 2011 tentang Perubahan Atas Undang-Undang Nomor 22 Tahun 2004 tentang Komisi Yudisial.

20 Undang-undang Repubulik Indonesia Nomor 18 Tahun 2011 tentang Perubahan Atas Undang-undang Nomor 22 Tahun 2004 Tentang Komisi Yudisial. 
Secara substansial UndangUndang Nomor 18 Tahun 2011 tersebut memuat ketentuan-ketentuan mengenai penguatan kelembagaan, mempertegas wewenang yang telah ada, dan menambah wewenang baru. Penguatan kelembagaan dinyatakan dalam ketentuan yang memberikan tugas kepada Sekretariat Jenderal untuk memberikan dukungan teknis operasional dan teknis administratif.

Komisi Yudisial juga diberikan wewenang untuk membentuk Penghubung di daerah sesuai kebutuhan. Penegasan wewenang dinyatakan dalam ketentuan yang menjabarkan wewenang menjaga dan wewenang menegakkan Kode Etik dan Pedoman Perilaku Hakim secara lebih rinci serta memberikan jalan keluar apabila rekomendasi Komisi Yudisial tidak ditindaklanjuti oleh Mahkamah Agung. Beberapa wewenang dan tugas baru Komisi Yudisial dalam Undangundang Nomor 18 Tahun 2011 adalah sebagai berikut:

a) Melakukan seleksi pengangkatan hakim ad hoc di Mahkamah Agung kepada DPR untuk mendapatkan persetujuan;

b) Melakukan upaya peningkatan kapasitas dan kesejahteraan hakim;

c) Menjaga dan menegakkan kehormatan, keluhuran martabat, serta perilaku hakim;

d) Menetapkan Kode Etik dan/atau Pedoman Perilaku Hakim bersama-sama dengan Mahkamah Agung; dan

e) Menjaga dan menegakkan pelaksanaan Kode Etik dan/atau Pedoman Perilaku Hakim. $^{21}$

Dengan disahkannya Undang-Undang Nomor 18 tahun 2011 tentang Perubahan Atas Undang-Undang Nomor 22 Tahun 2004 tentang Komisi Yudisial merupakan konkritisasi dari tekad dan semangat pemerintah dan DPR sebagai pembuat undang-undang untuk memperkuat wewenang dan tugas Komisi Yudisial sebagai lembaga negara independen yang menjalankan fungsi check and balances di bidang kekuasaan kehakiman, dalam rangka mewujudkan kekuasaan kehakiman yang merdeka untuk menegakkan hukum dan keadilan bagi seluruh rakyat Indonesia.

\footnotetext{
${ }^{21}$ Pasal 13 Undang-Undang Nomor 18 Tahun 2011.
} 
Ketentuan-ketentuan yang diatur dalam Undang-Undang Nomor 18 Tahun 2011 sebagaimana diuraikan di atas perlu dijabarkan lebih lanjut dalam Garis Besar Kebijakan dan Strategi Komisi Yudisial Tahun 2012-2016. Dengan kondisi di atas, keberadaan Komisi Yudisial sebagai lembaga pengawas eksternal perlu diperkuat untuk memastikan berjalannya proses peradilan yang bersih, merdeka dan bertanggung jawab. Komisi Yudisial harus mampu menjadi pilar utama dan berkontribusi maksimal dalam mewujudkan peradilan bersih dan membentuk pribadi hakim yang berintegritas, jujur, adil, dan profesional dalam rangka menegakkan kebenaran dan keadilan di Indonesia.

\section{a. Peraturan Perundang-undangan}

Komisi Yudisial merupakan lembaga negara independen yang dibentuk untuk menciptakan mekanisme dan fungsi check and balances di bidang kekuasaan kehakiman. ${ }^{22}$ Pelaksanaan wewenang dan tugas Komisi Yudisial tidak dapat dilepaskan dari landasan hukum yang mendasarinya. Beberapa peraturan perundang-undangan yang berkaitan dengan pelaksanaan wewenang dan tugas Komisi Yudisial adalah sebagai berikut:

1) Wewenang dan tugas Komisi Yudisial mengacu pada Pasal $24 \mathrm{~B}$ Undang-Undang Dasar Negara Republik Indonesia Tahun 1945 dan Undang-Undang Nomor 22 Tahun 2004 tentang Komisi Yudisial sebagaimana telah diubah dengan Undang-Undang Nomor 18 Tahun 2011 tentang Perubahan Atas Undang-Undang Nomor 22 Tahun 2004 tentang Komisi Yudisial;

2) Pelaksanaan wewenang mengusulkan pengangkatan calon hakim agung kepada DPR mengacu pada Undang-Undang Nomor 14 Tahun 1985 tentang Mahkamah Agung sebagaimana telah diubah terakhir dengan Undang-Undang Nomor 3 Tahun 2009 tentang Perubahan Kedua Atas Undang-Undang Nomor 14 Tahun 1985 tentang Mahkamah Agung; Undang-Undang Nomor 22 Tahun

\footnotetext{
${ }^{22}$ Keputusan Bersama Ketua Mahkamah Agung RI Dan Ketua Komisi Yudisial RI tentang Kode Etik Dan Pedoman Perilaku Hakim, Nomor. 047/KMA/SKB/IV/2009 dan 02/SKB/P.KY/IV/2009.
} 
Politica, Vol. 7, No. 2, Juli-Desember 2020

2004 tentang Komisi Yudisial sebagaimana telah diubah dengan UndangUndang Nomor 18 Tahun 2011 tentang Perubahan Atas UndangUndang Nomor 22 Tahun 2004 tentang Komisi Yudisial; UndangUndang Nomor 48 Tahun 2009 tentang Kekuasaan Kehakiman; dan Peraturan Komisi Yudisial Nomor 7 Tahun 2011 tentang Tata Cara Seleksi Calon Hakim Agung;

3) Pelaksanaan wewenang melakukan seleksi pengangkatan hakim mengacu pada Undang-Undang Nomor 2 Tahun 1986 tentang Peradilan Umum sebagaimana telah diubah dengan UndangUndang Nomor 49 Tahun 2009 tentang Perubahan Kedua Atas Undang-Undang Nomor 2 Tahun 1986 tentang Peradilan Umum; Undang-Undang Nomor 5 Tahun 1986 tentang Peradilan Tata Usaha Negara sebagaimana telah diubah terakhir dengan UndangUndang Nomor 51 Tahun 2009 tentang Perubahan Kedua Atas Undang-Undang Nomor 5 Tahun 1986 tentang Peradilan Tata Usaha Negara; Undang-Undang Nomor 7 Tahun 1989 tentang Peradilan Agama sebagaimana telah diubah dengan UndangUndang Nomor 50 Tahun 2009 tentang Perubahan Kedua Atas Undang-Undang Nomor 7 Tahun 1989 tentang Peradilan Agama; Undang-Undang Nomor 22 tahun 2004 tentang Komisi Yudisial sebagaimana telah diubah dengan Undang-Undang Nomor 18 Tahun 2011 tentang Perubahan Atas Undang-Undang Nomor 22 Tahun 2004 tentang Komisi Yudisial; dan UndangUndang Nomor 48 Tahun 2009 tentang Kekuasaan Kehakiman.

4) Pelaksanaan wewenang seleksi pengangkatan hakim ad hoc di Mahkamah Agung mengacu pada Undang-Undang Nomor 18 Tahun 2011 tentang Perubahan Atas Undang-Undang Nomor 22 Tahun 2004 tentang Komisi Yudisial.

5) Pelaksanaan wewenang menjaga dan menegakkan kehormatan, keluhuran martabat, serta perilaku hakim mengacu pada UndangUndang Nomor 2 Tahun 1986 tentang Peradilan Umum sebagaimana telah diubah terakhir dengan Undang-Undang Nomor 49 Tahun 2009 tentang Perubahan Kedua Atas Undang-Undang Nomor 2 Tahun 1986 tentang Peradilan Umum; Undang-Undang Nomor 5 Tahun 1986 tentang Peradilan Tata Usaha Negara 
sebagaimana telah diubah terakhir dengan Undang-Undang Nomor 51 Tahun 2009 tentang Perubahan Kedua Atas Undang-Undang Nomor 5 Tahun 1986 tentang Peradilan Tata Usaha Negara; Undang-Undang Nomor 7 Tahun 1989 tentang Peradilan Agama sebagaimana telah diubah dengan Undang-Undang Nomor 50 Tahun 2009 tentang Perubahan Kedua Atas Undang-Undang Nomor 7 Tahun 1989 tentang Peradilan Agama; Undang-Undang Nomor 22 tahun 2004 tentang Komisi Yudisial sebagaimana telah diubah dengan Undang-Undang Nomor 18 Tahun 2011 tentang Perubahan Atas Undang-Undang Nomor 22 tahun 2004 tentang Komisi Yudisial; Undang-Undang Nomor 48 Tahun 2009 tentang Kekuasaan Kehakiman; Surat Keputusan Bersama Mahkamah Agung dan Komisi Yudisial Nomor: 047/KMA/SKB/IV/200902/SKB/P.KY/IV/2009 tanggal 8 April 2009 tentang Kode Etik dan Pedoman Perilaku Hakim; Keputusan Bersama (SKB) antara Ketua Mahkamah Agung dan Ketua Komisi Yudisial Nomor 129/KMA/SKB/IX/2009, 04/SKB/P.KY/IX/2009 tentang Tata Cara Pembentukan, Tata Kerja dan Tata Cara Pengambilan Keputusan Majelis Kehormatan Hakim; Peraturan Komisi Yudisial Nomor 1 Tahun 2006 tentang Tata Cara Pengawasan Hakim yang sebagaimana telah diubah dengan Peraturan Komisi Yudisial Nomor 3 Tahun 2011 tentang Tata Cara Pengawasan Hakim; dan Peraturan Komisi Yudisial Nomor 4 Tahun 2011 tentang Tata Cara Penanganan Laporan Masyarakat;

6) Pelaksanaan wewenang melakukan seleksi pengangkatan hakim mengacu pada Undang-Undang Nomor 2 Tahun 1986 tentang Peradilan Umum sebagaimana telah diubah dengan UndangUndang Nomor 49 Tahun 2009 tentang Perubahan Kedua Atas Undang-Undang Nomor 2 Tahun 1986 tentang Peradilan Umum; Undang-Undang Nomor 5 Tahun 1986 tentang Peradilan Tata Usaha Negara sebagaimana telah diubah terakhir dengan UndangUndang Nomor 51 Tahun 2009 tentang Perubahan Kedua Atas Undang-Undang Nomor 5 Tahun 1986 tentang Peradilan Tata Usaha Negara; Undang-Undang Nomor 7 Tahun 1989 tentang Peradilan Agama sebagaimana telah diubah dengan 
Politica, Vol. 7, No. 2, Juli-Desember 2020

UndangUndang Nomor 50 Tahun 2009 tentang Perubahan Kedua Atas Undang-Undang Nomor 7 Tahun 1989 tentang Peradilan Agama; Undang-Undang Nomor 22 tahun 2004 tentang Komisi Yudisial sebagaimana telah diubah dengan Undang-Undang Nomor Tahun 2011 tentang Perubahan Atas Undang-Undang Nomor 22 tahun 2004 tentang Komisi Yudisial; dan UndangUndang Nomor 48 Tahun 2009 tentang Kekuasaan Kehakiman.

\section{Kesimpulan}

Agar terciptanya peradilan yang bersih di mana dalam Pasal 20 Undang-undang Republik Indonesia Nomor 18 Tahun 2011 tentang Perubahan Atas Undang-undang Nomor 22 Tahun 2004 tentang Komisi Yudisial, terdapat wewenang dan tugas dalam pemantauan dan pengawasan perlikau hakim. Dengan mengimplementasikan bunyi pasal tersebut Komisi Yudisial (KY) berperan melakukan pemantaun persidangan dalam lembaga peradilan. Dalam Pasal 20 Undang-undang Republik Indonesia Nomor 18 Tahun 2011 tentang Perubahan Atas Undang-undang Nomor 22 Tahun 2004 tentang Komisi Yudisial. Komisi Yudisial berkewajiban menerima laporan dari masyarakat untuk selanjutnya ditindaklanjuti sesuai dengan ketentuan perundangundangan demi keadilan bagi masyarakat yang menginginkan terciptanya peradilan yang bersih.

\section{Daftar Pustaka}

Aditya Mardiastuti, 'Kasus Suap Di MK', dalam http//www.detik News.com, diakses tanggal 01 Juni 2020, Pukul 10.25.

Direktori Putusan Mahkamah Agung Republik Indonesia Nomor 10/Pid.Sus-TPK/2014/PN.Jkt.Pst. Tentang Tindak Pidana Pencucian Uang Sengketa Pilkada Di MK.

Direktori Putusan Mahkamah Agung Republik Indonesia Nomor 81/Pid.Sus-TPK/2017/PN.Jkt.Pst. Tentang Tindak Pidana Korupsi Secara Besama-sama Dan Berlanjut. 
Politica, Vol. 7, No. 2, Juli-Desember 2020

Fitri Rachmawati, 'Komisi Yudisial', dalam http//www.kompas.com, diakses tanggal 06 Juni 2020, Pukul 21.00.

Icha Rastika,'Penangkapan Akil Mochtar', dalam http//www. kompas.com, diakses tanggal 01 Juni 2020, Pukul 10.30.

Keputusan Bersama Ketua Mahkamah Agung RI Dan Ketua Komisi Yudisial RI tentang Kode Etik Dan Pedoman Perilaku Hakim, Nomor. 047/KMA/SKB/IV/2009 dan 02/SKB/P.KY/IV/2009.

Nur Ahsan, 'Komisi Yudisial Dalam Pengawasi Hakim Perspektif Peradilan Islam', Jurnal Agama Dan Hak Azazi Manusia, Vol. 2, Nomor 2 Mei 2013, pp. 308.

Pasal 13 Undang-Undang Nomor 18 Tahun 2011.

Pasal 20A ayat (1) Poin c Undang-undang Republik Indonesia Nomor 18 Tahun 2011 tentang Perubahan Atas Undang-undang Nomor 22 Tahun 2004 tentang Komisi Yudisial.

Peraturan Komisi Yudisial Nomor 4 Tahun 2009 tentang Tata Cara Penanganan Laporan Pengaduan Masyarakat.

Peraturan Komisi Yudisial Nomor 7 Tahun 2011 tentang Perubahan Atas Peraturan Komisi Yudisial Nomor 2 Tahun 2009 tentang Tata Cara Seleksi calon Hakim Agung.

Peraturan Komisi Yudisial Republik Indonesia Nomor 2 Tahun 2012 tentang Garis Besar Kebijakan Dan Strategi Komisi Yudisial Tahun 2012-2016.

Peraturan Komisi Yudisial Republik Indonesia Nomor 2 Tahun 2016 tentang Seleksi Calon Hakim Agung.

Undang-undang Nomor 22 Tahun 2004 tentang Komisi Yudisial.

Undang-Undang Nomor 48 Tahun 2009 tentang Kekuasaan Kehakiman.

Undang-Undang Nomor 49 Tahun 2009 tentang Perubahan Kedua Atas Undang-Undang Nomor 2 Tahun 1986 tentang Peradilan Umum. 
Politica, Vol. 7, No. 2, Juli-Desember 2020

Undang-Undang Nomor 50 Tahun 2009 tentang Perubahan Kedua Atas Undang-Undang Nomor 7 Tahun 1989 tentang Peradilan Agama.

Undang-Undang Nomor 51 Tahun 2009 tentang Perubahan Kedua Atas Undang-Undang Nomor 5 Tahun 1986 tentang Peradilan Tata Usaha Negara.

Undang-undang Republik Indonesia Nomor 18 Tahun 2011 tentang Perubahan Atas Undang-undang Nomor 22 Tahun 2004 Tentang Komisi Yudisial. 